\title{
Bioassays : a comparative study of three parameters related to phosphorus bioavailability (yield, growth rate and intra- cellular concentration of phosphorus)
}

\author{
M. Hanna! \\ A. Dauta1
}

Bioassays have been carried out with the green alga Scenedesmus crassus in order to elaborate a technique for evaluating phosphorus bioavailability. This was achieved by the use of three parameters related to the uptake of this element (yield, growth rate and intracellular concentration of phosphorus). Judging from the results obtained, the most reliable parameter is the yield. This parameter is well correlated with intracellular concentration of phosphorus which has the advantage of being measured after 10 days. Coupling these two parameters enables a sharper analysis of a wider array of samples and supplements the data provided.

Blotests : étude comparative de trois paramètres liés à la biodispontbłlité du phosphore (biomasse maximale produite, taux de croissance, concentration intracellulaire de phosphore).

Des bioessais ont été réalisés avec une algue Chlorophycée, Scenedesmus crassus, afin d'élaborer une technique permettant d'évaluer la biodisponibilité du phosphore. Dans ce but, trois paramètres liés à l'assimilation de cet élếment (biomasse maximale produite, taux de croissance et cencentration intracellulaíre de phosphore) ont été utilisés. Les résultats obtenus montrent que la biornas se maximale produite est le paramètre le plus fiable. Ce paramètre est bien corrélé avec la concentration intracellulaire de phosphore qui, elle, présente l'avantage d'être mesurée au bout de dix jours. L'association de ces deux paramètres offre une analyse plus précise d'un éventail plus étendu d'échantillons.

\section{1. - Introduction}

The abundance and composition of algal communities as well as planktonic growth are primarily influenced by the availability of nutrients (Shoaf 1978). The " key " element, most of ten the limiting factor to phytoplankton populations, is phosphorus. The role of phosphorus in the eutrophication process of surface waters has been demonstrated (Vallentyne 1975). Many authors, including Vollenweider (1975), Dillon and Rigler (1974) and Schindler et al (1973) have tried to establish a predictable relationship between the phosphorus load of a lake (amount of phosphorus input/surface unit of water) and the amount of phytoplankton growing in a lake.

1. Laboratoire d'Hydrobiologie, ERA 702 du C.N.R.S., Univer. sité Paul Sabatier, 118, route de Narbonne, 31062 Toulouse Cedex, France.
One of the impediments to the use of these models resides in the assessment of the phosphorus fraction potentially useable by algae.

Numerous methodological approaches have been designated to evaluate the algal growth potential of natural waters. The most natural process for estimating the bioavailability of phosphorus for algae consists of testing the water through bioassays. The increasing utilization of bioassays for evaluating the fertility of waters has resulted in a tremendous array of possible useful parameters. The aim of this work is to introduce a comparative study of the following three parameters: yield, growth rate and intracellular concentration of phosphorus.

Evaluation of the phytoplankton production potential of natural waters based on chemical analysis of phosphorus compounds gives merely a rough idea of the bioavailability of this element but lacks accuracy because this method does not differentiate 
between the assimilable forms of phosphorus and those which are not. This type of information can only be obtained from bioassays.

In the United States, "The Algal Assay Procedure * is now widely applied to the quantitative study of eutrophication. This test was developed with the purpose of comparing the potential of water samples originating from distinct geographical areas or distinct laboratories. After extensive research this test gave rise to "The Selenastrum capricomutum Printz Algal Assay Bottle Test * (USEPA 1978). Various parameters have aided in characterizing algal growth potential in natural waters. Among these parameters, the most common are :

- intracellular concentrations of the main elements, particularly phosphorus (Gerloff and Skoog 1954 ; Gerloff 1957 ; Gerloff and Krombholz 1966 ; Serruya and Berman 1975); of :

- organic synthesis evaluated by measurements

. uptake kinetics (Rhee 1973) ;

- production (Fitzgerald 1970; Cain and Trainor 1973 ; Klotz, Cain and Trainor 1975 ; Gargas and Pedersen 1974) or biomass (Doemel and Brooks 1972, 1975 ; Serruya and Berman 1975 ; Keenan and Auer 1974) quantified by parameters such as: 1) algal photosynthesis (Bombowna and Bucka 1972 ; Keenan and Auer 1974) or carbon uptake (Grobbler and Davies 1979) ; 2) chlorophyll content (Cullimore and McCann 1972 ; Clasen and Bernhardt 1974 ; Serruya and Berman 1975 ; Panczakowa and Kotlinskaniedzielska 1977);

- phosphatase activity and liberation of orthophosphate (Fitzgerald and Nelson 1966 ; Fitzgerald 1969 ; Berman 1969 and 1970 ; Berman, Pollingher and Gophen 1972) ;

- chemical analysis of the mineral elements contained in water samples subjected to bioassays (Chamberlain and Shapiro 1969).

\section{2. - Experimental comparison of the three parameters related to phos- phorus bioavailability}

In order to evaluate the phosphorus bioavailability in water, we resorted to three parameters related to the uptake of this element : 1) yield ; 2) growth rate ; 3 ) intracellular concentration of phosphorus.
The choice of these three parameters was dictated by their different characterization of the same problem. The yield has the advantage of represen. ting the system's resultant : it integrates everything, uptake as well as growth. The determination of growth rate is very quick. The analysis of the intracellular concentration of phosphorus is undoubtedly the most direct measure of the bioavailability of phosphorus in water.

\section{3. - Methods}

Since this study aims at the elaboration of a tech. nique allowing the establishment of the relationships existing between the total quantity of phosphorus in water and the quantity of phosphorus available for phytoplankton, it is preferable to work on water for which the quantity as well as the forms of phosphorus are known. The water used for these bioassays was made up of the culture medium described by Brunel-Delclaux \& Guerri (1980) in which approximately 600 microgrammes/liter of orthophosphate added as $\mathrm{K}_{2} \mathrm{HPO}_{4}$ and approximately 100 microgrammes/liter of cellular phosphorus incorporated as Scenedesmus crassus cells, this instead of the prescribed concentration of $\mathrm{K}_{2} \mathrm{HPO}_{4}$. Samples of natural water originating from various sources were also tested.

In this type of biossay, the water samples are generally filtered (fiberglass filters, Whatman GF/C) before inoculation with the test organism, this, in order to eliminate indigenous algal populations. But we decided to work on filtered as well as unfiltered (autoclaved at $110^{\circ} \mathrm{C}$ for 30 minutes or 10 minutes per liter) water samples. The reason justifying this choice is that filtration removes particulate phosphorus as well as a fraction of the orthophosphate.

The bioassays were carried out using the " batch * technique and an alternative of the a Bottle Test * developed by Steemann Nielsen and Hansen (1961). The sterilized water samples were inoculated with Scenedesmus crassus and incubated at $25^{\circ} \mathrm{C}$ with a light intensity of $5.7 \mathrm{Klx}$ for a cycle of $15 / 9$, that is, 15 hours of constant light followed by 9 hours of darkness.

Since these bioassays were executed with monospecific populations, the yield could be deduced by measuring the cultures'optical densities at $678 \mathrm{~nm}$, following Cloern (1976) and Brunel-Delclaux and 
Guerri (1980). The cultures were kept until stagnation of growth ocurred because of lack of phosphorus, all other nutrients being in excess.

Since there is a relationship between optical density at $678 \mathrm{~m}$ and the density of the cells, for a constant growth rate in function of time and for measurements of optical densities taken daily at the same hour :

growth rate $=\log$. O.D. $\left(t_{2}\right)$ /O.D. $\left(t_{1}\right)$.
The intracellular concentrations of phosphorus were measured, following acid hydrolysis by the Persulfate digestion method (APHA, AWWA and WPFC, 1971), by Stephens' (1963) Method after 6, 24, 72 and 240 hours of growth after the beginning of the bioassays.

A schematic presentation of the experimental work is given on diagram 1.

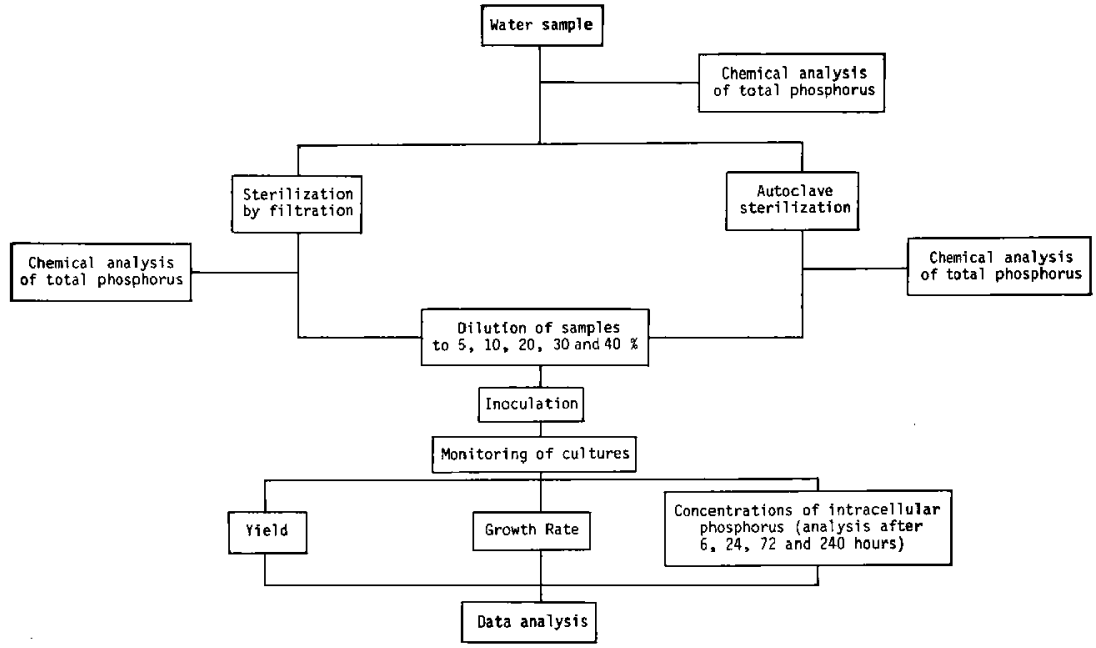

Diagram 1. - Assay flow chart.

\section{3. - Results}

\section{1. - Standard curves}

Figure 1 illustrates the growth curves of Scenedesmus crassus in various cultures containing increasing concentrations of phosphorus. These results enable the plotting of figures 3 and 5, which represent respectively the yield and growth rates versus increasing initial concentrations of $\mathrm{P}_{-} \mathrm{PO}_{4}$. The maximal yield of the culture is usually attained within three weeks ; it increases linearly with increa- sing initial concentrations of phosphorus, this with a correlation of $99 \%$. Referring to each growth curve (fig. 1), we observe that, right after inoculation growth resumes rapidly, and maximum growth rates occur the first or second day according to the initial additions of phosphorus. The evolution of growth rate versus initial concentrations of phosphorus follows a hyperbolic law attaining an asymptote at concentrations of 300 microgrammes/liter.

In order to verify the appropriateness of our bioassay technique, a laboratory prepared water sample was submitted to these tests, the resulting values were plotted as growth curves (fig. 2) for dif- 
ferent dilutions of the water sample : filtered and unfiltered fractions. From these growth curves were deduced the associated values of yield (fig. 4) and growth rates (fig. 6). Simultaneously, intracellular phosphorus uptakes at the end 6, 24, 72 and 240 hours were plotted versus the dilutions of the filtered and unfiltered water samples (fig. 8). Complete data of this application to the laboratory prepared water sample is summed up on table 1 . While phosphorus bioavailability infered using yield and intracellular phosphorus uptakes appear satisfactory, the results obtained through growth rate are incoherent since they overestimate the initial phosphorus concentrations.

Table I. - Phosphorus bioavailability as estimated through bioassays on laboratory prepared water sample.

The initial concentration of total phosphorus determined by chemical analysis, being.

Filtered water : $575 \mu \mathrm{g} /$ l. Unfiltred water : $665 \mu \mathrm{g} / \mathrm{l}$.

\begin{tabular}{|c|c|c|c|c|c|c|}
\hline \multirow{3}{*}{ Parameters } & & \multicolumn{4}{|c|}{ Phosphorus bioavailability } & \multirow{3}{*}{$\begin{array}{c}\text { Difference of productivity } \\
\text { between filtered and } \\
\text { filtered samples }(\%)\end{array}$} \\
\hline & & \multicolumn{2}{|c|}{ Filtered water } & \multicolumn{2}{|c|}{ Unfiltered water } & \\
\hline & & $\mu \mathrm{g} / 1$ & $\begin{array}{l}\% \text { of total } \\
\text { phosphorus }\end{array}$ & $\mu \mathrm{g} / 1$ & $\begin{array}{l}\% \text { of total } \\
\text { phosphorus }\end{array}$ & \\
\hline Maximal & yield & 575 & 86.47 & 640 & 96.24 & 9.77 \\
\hline Growth & Rate & 800 & & 1480 & & \\
\hline $\begin{array}{l}\text { Intracellular concentration } \\
\text { of phosphorus }\end{array}$ & $\begin{array}{r}6 \mathrm{~h} \\
24 \mathrm{~h} \\
72 \mathrm{~h} \\
240 \mathrm{~h}\end{array}$ & $\begin{array}{l}450 \\
460 \\
464 \\
506\end{array}$ & $\begin{array}{l}67.67 \\
69.17 \\
69.77 \\
76.20\end{array}$ & $\begin{array}{l}530 \\
535 \\
538 \\
700\end{array}$ & $\begin{array}{r}79.70 \\
80.35 \\
80.90 \\
100.00\end{array}$ & $\begin{array}{l}12.03 \\
11.28 \\
11.13 \\
23.80\end{array}$ \\
\hline
\end{tabular}

Table 2. - Phosphorus bioavailability of natural water samples as estimated through bioassays.

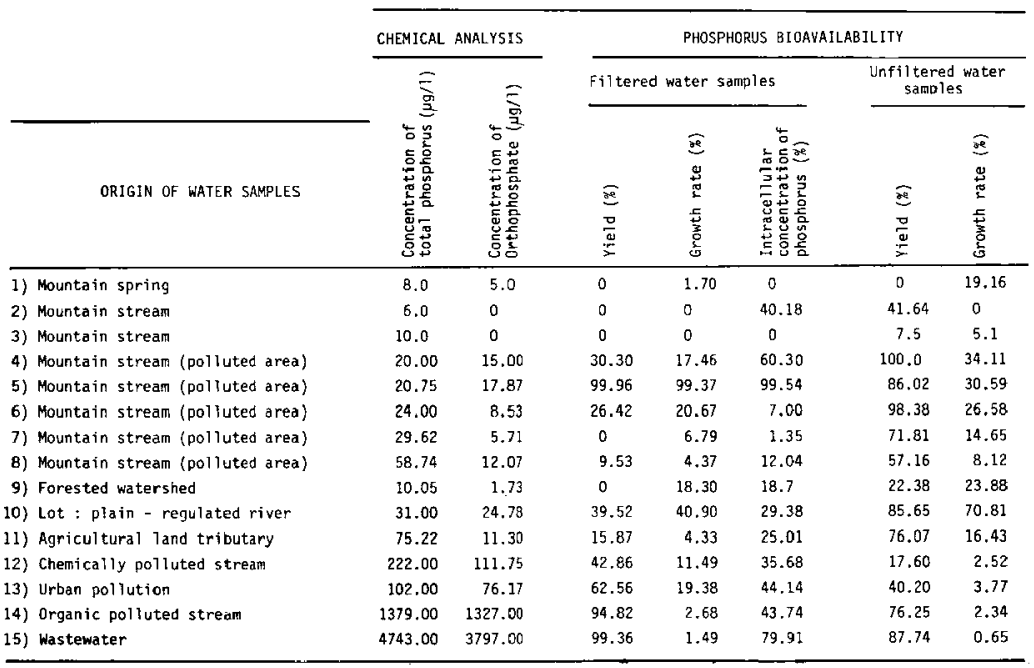




\section{2. - Natural water samples}

With the purpose of completing our investigation, a wide range of natural water samples originating from areas of distinct land use, were tested with regard to the three described parameters (table 2). The resulting bioavailabilities vary widely, ranging from $O$ to $100 \%$, as a function of the water's origin. For very oligotrophic waters (samples 1, 2 \& 3), the response is limited due to the particularly low dis. solved phosphorus concentration, effectively, for these samples the response for the filtered fractions is null while the unfiltered samples were partially bioavailable. The bioavailability of sample 2 as determined by intracellular phosphorus uptake seems illogical, this can however be justifyed by the fact that it represents a mere 2,5 microgrammes/liter, and chemical phosphorus analysis methods become unreliable at such low concentrations. Sample 5 represents one of the rare cases where bioavailability obtained through growth rate coincides with that obtained by the two other parameters; the reason for this can be related, firstly to the relatively low concentrations of phosphorus and secondly because this phosphorus is almost wholly present as dissolved orthophosphate and is therefore immediately available for algal growth. For chemically polluted waters (sample 12), the responses obtained from the unfiltered water fraction are lower than the responses obtained from the filtered fraction, the sterilization pretreatment in the au toclave has modified the sample's chemical equilibrium, reducing the fraction of bioavailable phosphorus. This hypothesis has been verified by chemically analy sing the autoclaved sample. This phenomenon reappears for the other polluted water samples tested (samples 13, 14 and 15), where change occurs in the autoclave vitiating with error the results.
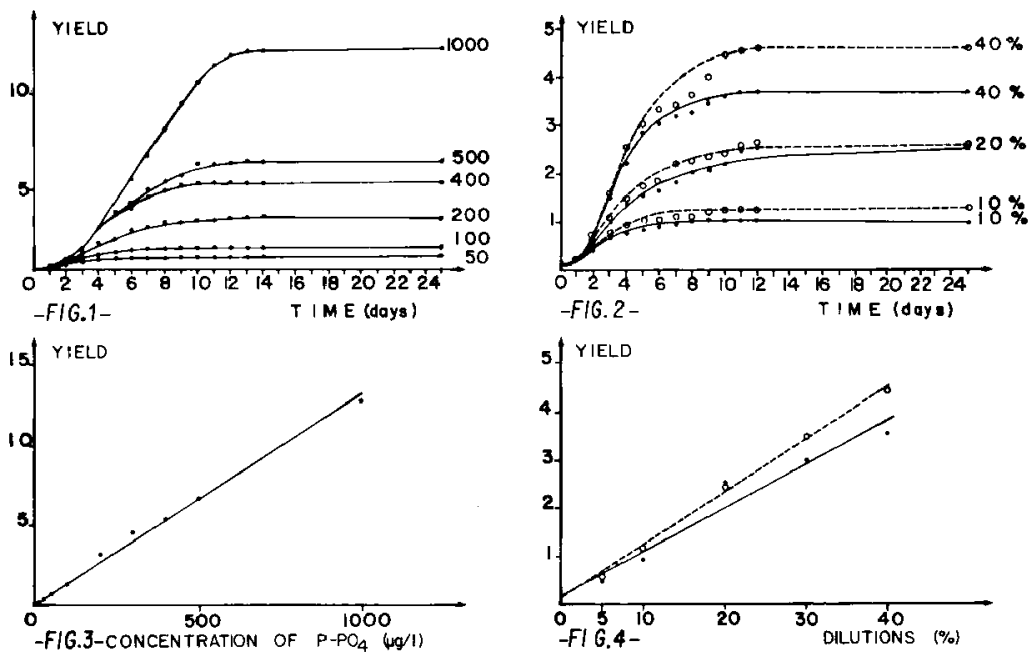

Fig. 1. Growth curves of Scenedesmus crassus for increasing concentrations of P.PO 4 .

Fig. 2. Growth curves of Scenedesmus crassus for different dilutions of the water sample : filtered ( $\rightarrow-)$ and unfiltered $(-0)$ ).

Fig. 3. Yield of Scenedesmus crassts as a function of increasing initial concentrations of $\mathbf{P}_{-P O}$.

Fig. 4. Yield of Scenedesmus crassus as a function of different dilutions of the water sample: filtered and unfiltered. 

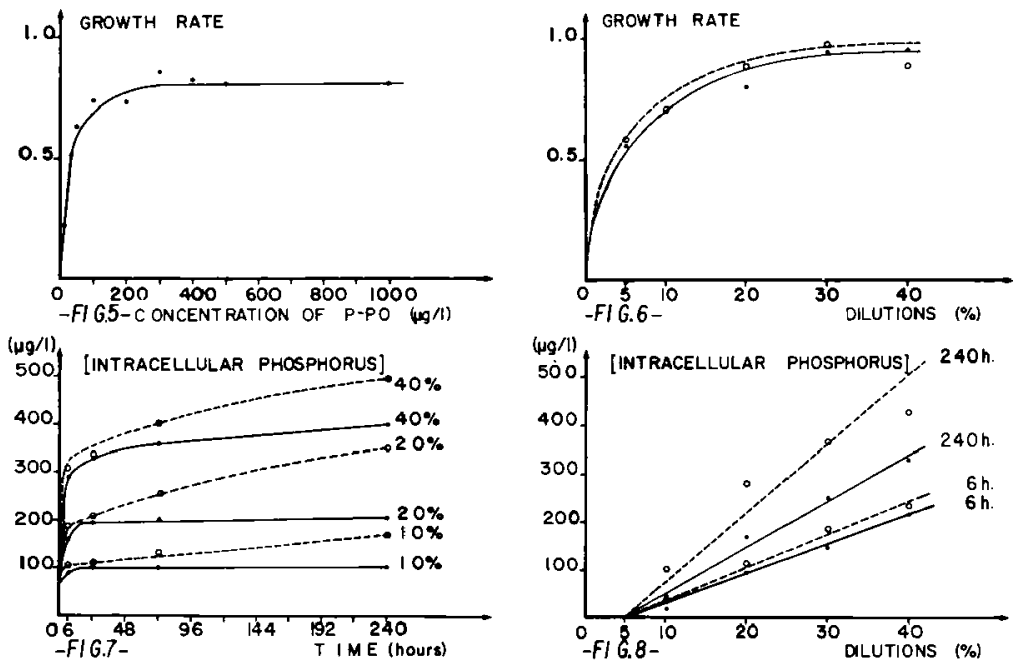

Fig. 5. Growth rate (between $O$ and 2 days) as a function of increasing initial concentrations of $P \cdot P_{4}$.

Fig. 6. Growth rate (between $O$ and 2 days) as a function of different dilutions of the water sample : filtered and unfiltered.

Fig- 7. Intracellular concentrations of phosphorus as a function of time for the different dilutions of the water sample : filtered and unfiltered.

Fig. 8. Intracellular concentrations of phosphorus uptake after 6 and 240 hours as a function of the different dilutions of the water sample : filtered and unfiltered.

\section{5. - Discussion}

The assessment of phosphorus bioavailability in water using three parameters related to the uptake of this element has enabled us to recognize the parameter best adapted for this measure.

Comparison of the biovailabilities estimated through the three parameters, generally favor yield as being the most faithful and reproducible parameter. The values obtained for phosphorus concentrations inferior to 100 microgrammes/liter are more reliable since this measurement involves neither artifacts caused by dilutions nor inaccuracy of spectrophotometer readings for O.D. higher than 1.3. Yield is the parameter most used for evaluating the quantitative responses of growth in batch cultures (Gargas and Pedersen 1974, USEPA 1978). The evolution of this parameter is easy to follow. The maximal yield of the cultures is somewhat independent of environmental factors, since it will eventually be attained, usually within three weeks. This measure is sufficiently sensitive to record a distinction between water samples having close potentialities.

Although the initial phosphorus concentrations determine the exponential growth rate of some batch cultures (Golterman et al. 1969, Rhee 1972, Thomas and Dodson 1968), growth rate should not be used as a bioavailability parameter since it is only indirectly related to external concentrations of nutrients. Laboratory studies have given evidence that growth rate is more sensitive to environmental factors since it is a dynamic parameter. Among these variables, let us state : light intensity, light-darkness cycles, temperature and the density of the organisms in water. Furthermore, the nutritive state of the 
algae before the bioassay is a determinant factor for the growth rate (Rhee 1973). The evolution of growth rate versus initial concentrations of phosphorus follows a hyperbolic law attaining an asymptote at concentrations of $\mathbf{3 0 0}$ microgrammes/liter : detection threshold of this parameter. However, Torien \& al. (1971) have demonstrated that for assessing toxicity, growth rate is a far more sensitive parameter than yield.

The recording of intracellular phosphorus uptake is the most direct approach to resolving the bioa. vailability of phosphorus in water although it entails a very tedious methodology. For waters of low phosphorus content (from $\mathbf{2 0}$ to $\mathbf{2 0 0}$ microgrammes/iter), this analysis has the advantage of presenting more accurate results. It is, however, subject to numerous sources of inaccuracy for waters containing very low or very high concentrations of phosphorus. Phosphorus uptake is also influenced by factors such as temperature, salinity, light intensity and light-darkness cycles. Furthermore, the algae's nutritive state before the bioassay is also a determinant factor (Rhee 1973). This method cannot be applied to the evaluation of phosphorus bioavailability for the long or short term if the maximal uptake rate is reached as a result of phosphorus saturation.

Careful examination of the advantages and limitations associated to earch of the three parameters tested, leads us to believe in the complementarity of at least the two following parameters : yield and intracellular concentration of phosphorus. Use of these two parameters together rather than limitation to only one of them, enables quite a good estimation of practically any water sample's bioavailability. Furthermore, since the calculation of growth rate is easily executed, this parameter can be used to detect a toxic or inhibitory factor.

Through the whole duration of the bioassays and for the three parameters studied, a majority of the unfiltered samples (the laboratory prepared water sample, as well as samples $1,2,3,4,5,6,7,8,9,10$ and 11) had significantly higher potential than the filtered samples, this additional bioavailability is assumed to be due to the particulate matter contained in each unfiltered sample. The contrary is true for samples 12 through 15 where the heat steriliza. tion pretreatment in the autoclave has evidently modified the natural chemical equilibrium, altering the test's response by reducing the bioavailable phosphorus fraction. This sterilization procedure is not appropriate for all water samples. Moreover, it is not applicable for measuring the intracellular phosphorus uptake of the unfiltered samples, since it does not al low the separation of algae from particulate matter.

\section{Acknowledgements}

The authors are indebted to Dr J. Capblance for valuable criticism of the manuscript and to Miss C. Mur for performing the phosphorus analysis.

\section{References}

APHA, AWWA \& WPFC. 1971. - Standard methods for the examination of water and wastewater. 13 th Ed., Amer. Pub. Health Assn, New York, 518-535.

Berman (T.) 1969. - Phosphatase release of inorganic phosphorus in lake Kinneret. Nature, 224, 1231-1232.

Berman (T). 1970. - Alkaline phosphatases and phosphorus availability in lake Kinneret. Limnol. Oceanogr. 15 (5), 663.674.

Berman (T)., Pollingher (U). \& Gophen (M). 1972. - Lake Kinneret : planktonic populations during seasons of high and low phos. phorus availability. Verh. int, verein. theor angew. Iimmol. 18. 588-598.

Bombowna (M.) \& Bucka (H.). 1972. - Bioassay and chemical composition of some Carpathian rivers. Verh. intemat, verein lim. not., 18, 735-741.

Brunel-Delclaux (L.) \& Guerri (M.M.). 1980. - Cinétiques d'assimilation et de croissance de Scenedesmus crassus. Etude experimentale et modelisation. These de doctorat de $3^{\circ}$ cycle. Université Paul Sabatier, Toulouse, ronétype, 226 p.

Cain (J.R.) \& Trainor (F.R.). 1973. - A bioassay comprise. Phyco logia, 12, 227-232.

Chamberlain (W.M.) \& Shapiro (J.). 1969. - On the biological significance of phosphate analysis : comparison of standard and new methods with a bioassay. Limnol. Oceanogr. 14, $921-927$.

Clasen (J.) \& Bermhardt (H.). 1974 - The use of algal assays for determining the effect of iron and phosphorus compounds on the growth of various algal species. Water Res. 8, 31-44.

Cloem (J.E.) 1976. - Population dynamics of Cryptomonas ovata. A laboratory field and computer simulation study. P.H.D. The sis Washington state university. Department of zoology, $102 \mathrm{p}$.

Cullimore (D.R.) \& McCann (A.) 1972. - Initial studies on a method of algal assay for nutrient parameters in water. $J$. Fish. Res. Bd Can. 29, 195-198.

Dillon (P.J.) \& Rigler (F.H.). 1974. - A test of a simple nutrient budget model predicting the phosphorus concentration in lake water. J. Fish. Res. Bd Can. 31, 1771-1778.

Doemel (W.N.) \& Brooks (A.E.). 1972. - A new algal assay to determine the growth potential of phosphons containing natural waters. Proc. Indiana Acad. Sci. 82, 1-98.

Doemel (W.N.) \& Brooks (A.E.), 1975. - Detergent phosphorus and algal growth. Water Res. 9, 713-719.

Fitzgerald (G.P.). 1969. - Field and laboratory evaluations of bioassays for nitrogen and phosphorus with algae and aquatic weeds. Limnol. Oceanogr. 14, 206-212. 
Fitzgerald (G.P.). 1970. - Evaluation of the availability of sources of nitrogen and phosphorus for algae. J. Phycol. 6, 239-247.

Fitzgerald (G.P.) \& Nelson (T.C). 1966. - Extractive and enzymatic analysis for limiting or surplus phosphorus in algae. J. Phycol. 2, 32-37.

Gargas (E.) \& Pederson (J.S.). 1974 - Algal assay procedure. Batch technique. Contributions from the water quality institute. Danish Academy of Technical Science, $n^{\circ} 1$

Gerloff (G.C.). 1957. - Nitrogen as a limiting factor for the growth of Microcystis aeruginosa in Southern Wisconsin Lakes. Eco$\log y, 38,556-561$.

Gerloff (G.C.). \& Skoog (F.). 1954 - Cell contents of nitrogen and phosphorus as a measure of their availability for growth of Microcystis aenuginosa. Ecology, 35, 348-353.

Gerloff (G.C.) \& Krombholtz. (1966). - Tissue analysis as a measure of nutrient availability for the growth of angiosperm aquatic plants. Limnol. Oceanogr. 11 (4), 529-537.

Golterman (H.L.), Bakels (C.L.) \& Jacobs-Mogelin (J.). 1969. - Availability of mud phosphates for growth of algae. Verh. intemat. verein limnol. 17, 467-479.

Grobler (D.C.) \& Davies (E.). 1979. - The use of WalkJey-Black method for organic carbon determination as a procedure for estimating algal yields. Water S. A. 5 (3), 138-143.

Keenan (J.D.) \& Auer (M.T.). 1974 - The influence of phosphorus luxury uptake on algal bioassays. J. Wat. Pollut. Control Fed. 46, 523-542.

Klotz (R.L.), Cain (J.R.) \& Trainor (F.R.). 1975. - A sensitive algal assay : an improved method for analysis of freshwaters. $J$. Phycot. 11, 411.414.

Panczakowa (J.1.) \& Kotlinska-Niedzielska (E.). 1977. - Phosphorus intake from organic compounds by algae of the genus Chlorella and Scenedesmus. Pol. Arch. Hydrobiol. 24 (2), 235-244.

Rhee (G.Y.). 1972. - Competition between an alga and an aquatic bacterium for phosphate. Limnol. Oceanogr. 17, 505-514.
Rhee (G.Y.). 1973. - A continuous culture study of phosphate uptake, growth rate and polyphosphate in Scenedesmus sp. J. Phycol. 9, 495-506.

Schindler (D.W.), Kling (H.), Schmidt (R.V.), Prokopowich (J.), Frost (V.E.), Reid (R.A.) Capel (M.). 1973. - Eutrophication of lake 227 by addition of phosphate and nitrate, the second, third and fourth years of enrichment 1970-71 and 1972. J. Fish. Res. Bd Can. 30, 1415.1440.

Serruya (C.) \& Berman (T.). 1975. - Phosphorus, nitrogen and the growth of algae for lake Kinneret. J. Phycol. 11 (2), 155-162.

Shoaf (W.T.). 1978. - Use of algal assays to determine the poterthal for phytoplankton growth. Hydrol. Sci. Bull. 23 (4), 439-444.

Steemann Nielsen (E.) \& Hansen (V.K.). 1961. - Influence of surface illumination on Plankton photosynthesis in Danish Waters $\left(56^{\circ}\right.$ N) throughout the year. Physiologia Pl. 14, 595-613.

Stephens (K.). 1978. - Determination of low phosphate concentrations on cell division rates and yield of a tropical oceanic diatom. Biol. Bull. 134, 199.208.

Toerien (D.F.), Huang (C.H.), Radimsky (J.), Pearson (E.A.) \& Scherfig (J.). 1971 - Final report, provisional algal assay procedure for the water quality office environmental protection agency. Project $n^{\circ} 16010$ DQB, SERL Report n ${ }^{\circ} 71-6$.

U.S. Environmental Protection Agency, National Eutrophication Research Program (1978) The Selenastrum carpicomutum printz algal assay bottle test. EPA, Pacific Northwest Laboratory, Convallis, Oregon.

Vallentyne (J.R.). (1975). The algal bowl. Department of the Envi. ronmental Fisheries and Marine Service. Miscellaneous special publication 22, Ottawa, Canada, 196 p.

Vollenweider (R.A.). 1975, - Input-output models, with special reference to the phosphorus loading concept in limnology. Schweiz Z. Hydrol. 37 (1) 53-84 